\title{
Arsenic Biotransformation as a Cancer Promoting Factor by Inducing DNA Damage and Disruption of Repair Mechanisms
}

\author{
Victor D. Martinez, ${ }^{1,2}$ Emily A. Vucic, ${ }^{1}$ Marta Adonis, ${ }^{2}$ Lionel Gil, ${ }^{2}$ and Wan L. Lam ${ }^{1}$ \\ ${ }^{1}$ Department of Integrative Oncology, BC Cancer Research Centre, 675 West 10th Avenue, Vancouver, BC, Canada V5Z 1L3 \\ ${ }^{2}$ Biomedical Sciences Institute, Faculty of Medicine, University of Chile, Independencia 1027, 8380453 Santiago, Chile
}

Correspondence should be addressed to Victor D. Martinez, vmartinez@bccrc.ca

Received 16 March 2011; Accepted 6 June 2011

Academic Editor: Frédéric Coin

Copyright (C) 2011 Victor D. Martinez et al. This is an open access article distributed under the Creative Commons Attribution License, which permits unrestricted use, distribution, and reproduction in any medium, provided the original work is properly cited.

\begin{abstract}
Chronic exposure to arsenic in drinking water poses a major global health concern. Populations exposed to high concentrations of arsenic-contaminated drinking water suffer serious health consequences, including alarming cancer incidence and death rates. Arsenic is biotransformed through sequential addition of methyl groups, acquired from s-adenosylmethionine (SAM). Metabolism of arsenic generates a variety of genotoxic and cytotoxic species, damaging DNA directly and indirectly, through the generation of reactive oxidative species and induction of DNA adducts, strand breaks and cross links, and inhibition of the DNA repair process itself. Since SAM is the methyl group donor used by DNA methyltransferases to maintain normal epigenetic patterns in all human cells, arsenic is also postulated to affect maintenance of normal DNA methylation patterns, chromatin structure, and genomic stability. The biological processes underlying the cancer promoting factors of arsenic metabolism, related to DNA damage and repair, will be discussed here.
\end{abstract}

\section{Introduction}

Arsenic is one of the most abundant elements in the Earth's crust [1]. Chemically, it is classified as metalloid, exhibiting organic (when linked with carbon and hydrogen) and inorganic (combined with oxygen, chlorine, and sulfur, among other elements) forms [2]. Inorganic arsenic (iAs) can be present naturally in soil, especially in rocks containing copper or lead, and in the atmosphere as airborne dust. Additionally, anthropogenic activities, such smelter operations, can cause water contamination $[3,4]$. In the environment, iAs can be found in several oxidation states, more frequently as trivalent (iAs[III], also known as arsenite) and pentavalent (iAs[V] or arsenate) species [5]. These forms are differently metabolized by mammals (see below) and exhibit distinct grades of toxicity.

Several health effects have been documented as a consequence of iAs exposition, with the majority of harmful exposure coming from ingestion through drinking water. iAs-associated malignancies include skin lesions, hypertension, ischemia, some endemic peripheral vascular disorders (e.g., "black foot disease"), severe arteriosclerosis, neuropathies, noticeably, many types of cancer [6-9]. A number of studies have established significant associations and/or dose response trends between iAs in drinking water and occurrence of tumors of the skin, bladder, kidney, liver, prostate, and lungs [10-15].

The evidence of a relationship between iAs in drinking water and cancer is extensive and sufficient, leading to the International Agency of Research on Cancer (IARC) to consider this metalloid as a Group 1 human carcinogen. The estimated cancer-death risk associated with daily consumption of 1.6 liters of water with iAs concentrations of $50 \mu \mathrm{g} / \mathrm{L}$ is $21 / 1,000$ [16]. For these reasons, the World Health Organization and the U.S. Environmental Protection Agency have recommended a threshold of $10 \mu \mathrm{g} / \mathrm{L}$ for iAs concentration in drinking water $[17,18]$.

Despite efforts to reduce high-scale exposure, many nations throughout the world have iAs concentrations in water that are above the recommended level [19-21]. Approximately 40 million people worldwide are thought to be exposed to iAs levels that can be considered dangerous 
[19]. Among them, 21 million people in Bangladesh and India (West Bengal) are exposed to drinking water with iAs concentrations $>50 \mu \mathrm{g} / \mathrm{L}$ [22], and shockingly, iAs concentration in water wells in these areas has been documented as high as $1000 \mu \mathrm{g} / \mathrm{L}$ [23]. In China, it has been estimated that more than 3 million people are exposed to iAs from groundwater [24], while in southwestern Taiwan, some residents have used well water contaminated with iAs for more than 50 years (some ingesting as much as $1000 \mu \mathrm{g}$ iAs/day) [25-27]. In Northern Chile, the population was exposed to levels of iAs in drinking water around $900 \mu \mathrm{g} / \mathrm{L}$ between 1958 and 1970, with nearby towns registering exposures of $600 \mu \mathrm{g} / \mathrm{mL}$ as late as 1994 [11].

\section{Arsenic Biotransformation}

About $80-90 \%$ of ingested As[III] or As[V] is absorbed from the gastrointestinal tract [28-30]. Data derived from autopsies has determined that muscles, bones, kidneys, and lungs have the highest absolute accumulated amounts of iAs, while skin and excretory/storage organs, such as nails and hair, are the most concentrated [31]. iAs[III] exhibits a significantly higher biological activity than As[V]; however, effects observed in mammals could be similar, since absorbed As $[\mathrm{V}]$ is mostly reduced to As[III] on the initial steps of arsenic metabolism in mammals [32, 33]. Interestingly, there is evidence for interindividual differences in iAs metabolism/excretion in humans and other species $[34,35]$.

The biotransformation process of iAs occurs via methylation through alternating reduction of As[V] to As[III], and subsequent addition of methyl groups [36]. This methylation process uses S-adenosylmethionine (SAM) as a methyl group donor, through a SAM-dependant As[III]-methyltransferase, initially isolated from rat liver and a human homologue of cytochrome19 [37]. This enzyme catalyzes the transfer of a methyl group from SAM to As[III] producing methylated and dimethylated arsenic compounds. Trivalent methylated species, such monomethylarsonous acid (MMA[III]) and dimethylarsinic acid (DMA[III]), have been detected in the urine of patients chronically exposed to iAs in drinking water [38, 39]. Methylated pentavalent arsenicals such as monomethylarsonic acid (MMA[V]) and dimethylarsinic acid (DMA $[\mathrm{V}])$ are major metabolites of iAs in human urine, with DMA[V] being the final metabolite in humans [3941]. Derivate methylated species from iAs metabolisms are considered relevant agents during arsenic carcinogenicity, specially through induction of oxidative stress and impairing DNA repair processes. These aspects will be discussed in the following sections.

Despite evidence of biotransformation role in arsenic carcinogenicity, it has been demonstrated that arsenic can induce malignant transformation in cell lines with deficient arsenic-methylation capacity. Arsenic methylation-deficient RWPE-1 human prostate cells undergo malignant transformation when exposed to $5.0 \mu \mathrm{M}$ of iAs[III] during 30 weeks [42]. Alternative mechanism of arsenic-induced malignant transformation might be associated with mitochondrial dysfunction (see below), specifically through transcription and replication of the mitochondrial genome, in which the mitochondrial transcription factor A (mtTFA) and its regulators, such the nuclear respiratory factor-1 (NRF-1), play key roles $[43,44]$. In this context, it has been demonstrated that mtTFA and NRF-1 expressions levels are increased in cells exposed to iAs[III] in a concentration-dependent manner, suggesting that arsenic regulates mitochondrial activity through an NRF-1-dependent pathway [45].

\section{Arsenic Carcinogenicity: Role of Oxidative Stress}

Despite the strong relationship between iAs exposure and cancer, the exact mechanism is still unknown. There is evidence supporting low level mutagenic activity of iAs; however, it has also been shown that iAs can induce transformation in several cell types $[46,47]$. Moreover, iAs can interfere with a number of biological processes, including DNA methylation, since the arsenic biotransformation pathway uses SAM as a methyl group donor. Therefore, epigenetic mechanisms have also been proposed to participate in iAsinduced carcinogenesis [48].

Biotransformation of $\mathrm{iAs}$ has been proposed to generate final and intermediate metabolites exhibiting higher toxicity and reactivity compared to originally ingested iAs [5, 49, 50]. Methylated species, especially DMA[V], have been demonstrated to be genotoxic and cytotoxic [46, 49, 5153]. Several studies have shown that DMA[V] can exhibit carcinogenic potential in mammals, mainly in lungs, skin, liver, kidney, thyroid, and urinary bladder [39, 54-58]. It has been proposed that DMA[V] can participate in promoting tumorigenesis of lungs and skin in mouse via the production of dimethylated arsenic peroxide $\left[\left(\mathrm{CH}_{3}\right)_{2} \mathrm{AsOO} \cdot\right]$, a type of reactive oxygen species (ROS) generated during iAs metabolism $[53,54]$.

In the light of these facts, oxidative stress has been proposed as a plausible general mode of action for iAs carcinogenesis [59-63]. Oxidative stress is characterized by generation of several ROS, such as superoxide anion $\left(\mathrm{O}_{2}{ }^{-}\right)$, hydroxyl radical $(\cdot \mathrm{OH})$, hydrogen peroxide $\left(\mathrm{H}_{2} \mathrm{O}_{2}\right)$, singlet oxygen $\left({ }^{1} \mathrm{O}_{2}\right)$, and peroxyl radical (LOO), among others [64]. One of the primary species formed in iAs-induced oxidative stress is $\mathrm{O}_{2}{ }^{-}$, followed by a cascade of secondary ROS such as $\mathrm{H}_{2} \mathrm{O}_{2}$ and $\cdot \mathrm{OH}[61]$.

iAs exposure results in the generation of ROS in various cellular systems, and its production has been proposed as one of the early biological events on iAs-related carcinogenic process [65]. In addition, cultured vascular endothelial cells exposed to iAs increase oxygen cell consumption contributing to increased ROS production, stimulating cell signaling and activating transcription factors [66]. Conversely, ROS scavengers can suppress arsenic-induced oxidative stress and its cytotoxic effects in cells $[67,68]$. It has also been described that iAs exposure can affect expression of genes associated with stress-related components, DNA damage and repairresponsive genes, activation of transcription factors such as the AP-1 complex, and increases in proinflammatory 
cytokines, which could influence response to acute arsenic toxicity [69]. Alternatively, ROS generation by iAs can involve hepatic and renal heme oxygenase isoform 1, generating among others species, free iron which subsequently participates in reactions where $\mathrm{H}_{2} \mathrm{O}_{2}$ is reduced to $\mathrm{OH}^{-}$and - OH [69]. Additionally, the oxidation of iAs[III] to As[V] during formation of intermediary arsine species can also generate $\mathrm{H}_{2} \mathrm{O}_{2}$ [70].

Mechanisms of iAs carcinogenicity could vary between different tissues, due to different oxygen concentrations, and accumulation of iAs species, endogenous reducing agents, and ferritin, among others factors [71, 72]. For example, lungs are exposed to the highest oxygen tensions in the body, and DMA[III], and its derivates (including ROS) are excreted through the lung, which could explain why this organ is frequently affected by iAs-induced carcinogens [60].

It has been suggested that arsenic-associated mitochondrial dysfunction, mitochondrial DNA (mtDNA) depletion, and induction of mtDNA deletions may contribute to the carcinogenicity in humans [73]. Also, mitochondria might be an important target of arsenic-induced genotoxicity [74]. On the other hand, since mitochondria is a major source of intracellular ROS, arsenic-mediated disruption of its function can lead to an increase in intracellular ROS levels and subsequently, to an increased mutagenic potential, either directly or by decreasing DNA repair capacity [73]. Relationships between mitochondria and arsenic-mediated effects are supported by observations such as suppression of arsenic-induced apoptosis in HeLa cells by the antioxidant action of $\mathrm{N}$-acetyl-cysteine, which prevents mitochondrial membrane depolarization [75]. Alternatively, arsenic can act directly through condensing mitochondrial matrix and opening of permeability transition pores [76].

\section{DNA and Chromosomal Damage by iAS-Induced Oxidative Stress}

Genotoxic mechanisms associated with arsenic carcinogenicity remain controversial. While some groups argue against this type of interaction, others have postulated this can be a significant mode of action. Rossman [46] has proposed that arsenite does not react directly with DNA. In the same way, toxic doses $(10-15 \mu \mathrm{M})$ of iAs[III] act as a poor mutagen at the gpt mutagenic target in transgenic Chinese hamster G12 cells [77]. On the other hand, it has been proposed that $\mathrm{iAs}[\mathrm{III}]$ is a significant mutagen that induces mainly large chromosomal mutations [78]. Alternatively, arsenic has been shown to be mutagenic to mitochondrial DNA and can potentially induce nuclear DNA damage by activating mitochondrial ROS through increased expression of mtTFA [45]. Also, arsenic can induce mutations as well as methylation changes in the mouse testicular Leydig cell genome [79]. Similarly, comet assay performed on human prostate epithelial cells exposed to $100 \mathrm{pg} / \mathrm{mL}$ of arsenic exhibited tail-like structures, suggesting induction of nuclear DNA damage [45].

iAs is known to damage chromosomes [80]. Due to little evidence of covalent binding between iAs and DNA structures, it has been proposed that much of the DNA damage observed during iAs exposure is indirect, occurring mainly as a result of ROS induction which generates DNA adducts, DNA strand breaks, cross links, and chromosomal aberrations [81, 82]. Figure 2 indicates the sequence of events related to ROS induced DNA damage after iAs exposure. Depending on which cell cycle phase exposure occurs, as a consequence DNA oxidation, iAs can result in gross chromosomal aberrations including DNA strand breaks [61, 69].

\section{DNA Strand Breaks}

iAs can induce DNA strand breaks even at low concentrations. Main related-events are summarized in Figure 1. Single-strand DNA (ssDNA) breaks are the most common lesions induced by exogenous genotoxins [83]. Arsenicinduced ssDNA breaks are likely caused through ROS, either directly by free-radical attack on the DNA bases or indirectly during the course of base excision repair (BER) mechanisms [84]. Arsenic-induced ROS has been shown to promote ssDNA breaks in mice lungs [70]. Furthermore, human fibroblast cell lines exposed to iAs exhibit ssDNA breaks and DNA-protein adducts, as well as sister chromatid exchanges [85].

iAs is also capable of producing double-strand DNA (dsDNA) breaks at concentrations of $5 \mu \mathrm{M}$ in mammalian cells [86]. These are one of the most deleterious and mutagenic DNA lesions experienced in human cells, leading to gross losses of genetic material [87]. Therefore, iAs is also proposed to act as a cocarcinogen, exacerbating damage induced by other agents. In this context, $1 \mu \mathrm{M}$ of iAs increases UVR-mediated DNA strand breaks by interfering with Poly-adenosine diphosphate-ribose polymerase 1 (PAPR-1) activity, which plays an important role in the ssDNA or dsDNA breaks repair process [88].

MMA[III] was found to be a potent clastogen in late G1- or S-phase-treated cells; however, lesions induced by MMA[III] are quickly repaired through BER mechanisms when they are induced in G0- or G1-phase of the cell cycle [84]. Trivalent arsenicals might induce either chromatidor chromosome-type aberrations during treatment in G0 or G1. If ssDNA or dsDNA breaks produced by iAsinduced ROS pass the S-Phase (DNA synthesis), replication occurs and chromatid- and chromosome-type aberrations can be produced [89]. Evidence pertaining to these type of aberrations is discussed below.

\section{Arsenic-Induced Chromatid and Chromosomal Aberrations}

Arsenic is a known inducer of chromosomal and chromatid aberrations. Lee et al. [90] demonstrated that iAs can effectively induce methotrexate-resistance in mouse 3T6 cells, resulting in selection of cells with amplification of the dihydrofolate reductase gene [91]. Genetic changes were observed in bladder tumor (transitional cell carcinoma, TCC) from 123 patients in Argentina and Chile, exposed to 


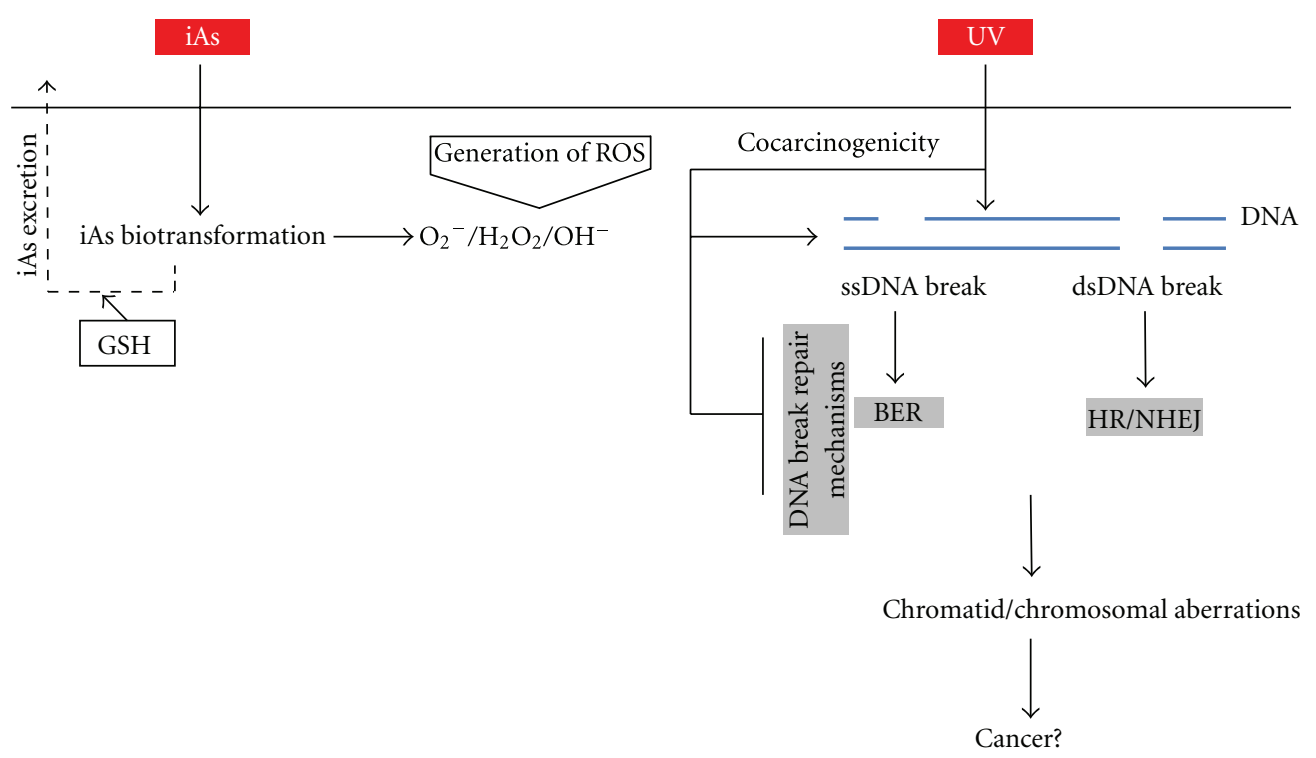

Figure 1: Arsenic-induced DNA strand breaks. After ingestion, iAs biotransformation process could lead to iAs excretion, mainly conjugated with Glutathione (GSH). On the other hand, biotransformation process may generate reactive oxygen species (ROS), probably in a specific sequence: superoxide anions $\left(\mathrm{O}_{2}{ }^{-}\right)$, hydrogen peroxide $\left(\mathrm{H}_{2} \mathrm{O}_{2}\right)$, and hydroxyl radicals $(\cdot \mathrm{OH})$. These species can induce both single-strand (ssDNA) and double-strand (dsDNA) breaks by inducing oxidative damage. In parallel, they can inhibit DNA break repair mechanisms both for ssDNA breaks (mainly base excision repair [BER]) and for dsDNA breaks (homologous recombination [HR] and/or nonhomologous end joining [NHEJ]). Additionally, ROS derived from iAs biotransformation can act as cocarcinogens, for example, increasing damage potential of ultraviolet (UV) light. All these events could be associated, in part, to iAs-related carcinogenic mechanism.

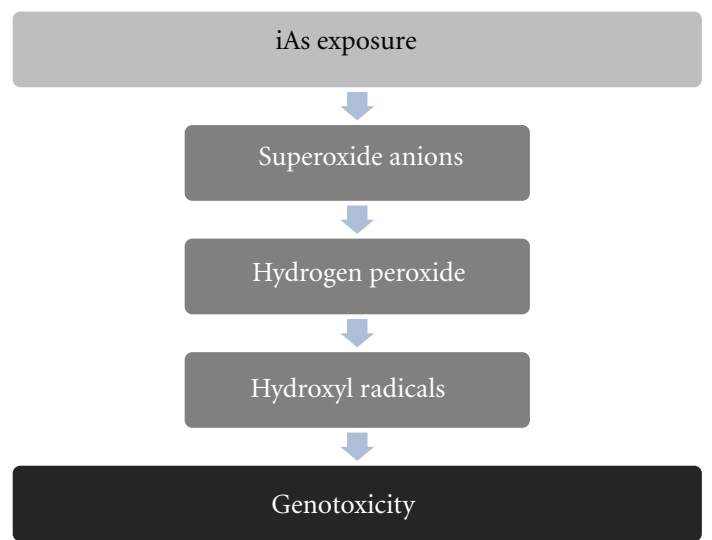

FIGURE 2: Events related with ROS-induced DNA damage after iAs exposure. Specific sequence of reactive oxygen species generation as a consequence of iAs biotransformation in mammals.

iAs concentrations exceeding $500 \mu \mathrm{g} / \mathrm{L}$. Individuals exposed to high As concentrations ( $>300-600 \mu \mathrm{g} / \mathrm{L})$ exhibited a higher total number of chromosomal aberrations, supporting the hypothesis that exposure to iAs increases genomic instability. Furthermore, chromosomal aberrations (specifically DNA copy-number alterations) were more abundant among iAs-exposed bladder TCC tumors from southwest Taiwan compared with nonexposed tumors from the same area [92]. Some alterations were common to those found in other studies, suggesting that nonrandom events are associated with As-induced urinary TCC formation and progression [93].

Other large-scale cytogenetic aberrations have been observed in iAs-exposed populations. Gonsebatt et al. [94] analyzed cytogenetic effects in individuals exposed to different levels of As in drinking water. People exposed to iAs at an average of $400 \mu \mathrm{g} / \mathrm{L}$ showed a significant increase in frequency of chromatid and isochromatid deletion in first-metaphase lymphocytes and micronuclei in oral and epithelial exfoliated cells compared to individuals with lower exposures. Women and children from the northeast Andean Region of Argentina exposed to $200 \mu \mathrm{g} / \mathrm{L}$ of iAs in drinking water displayed higher micronuclei frequency compared to people exposed to very low iAs concentrations, but did not have altered frequency of other aberrations, such as sister chromatid exchange, specific translocations, or cell-cycle progression [95].

\section{Oxidative Damage}

DNA modifications due to iAs-induced ROS can produce oxidative damage, which can be measured through the presence in urine of products of guanine oxidation in position 8 (8-oxo-2'-deoxyguanosine (8-oxodG), 8-hydroxyguanine [8-oxo-G], 8-hydroxyguanosine [8-oxy-Guo] and 8hydroxy-2'-deoxyguanosine [8-OHdG] [64]. After DMA[V] administration in terminal bronchiolar Clara cells from mice, markers for oxidative stress were detected, including 8-oxodG [96]. Additionally, it has been demonstrated that the presence of 8-OHdG was associated with administration 
of DMA[V] in iAs-related human keratoses, squamous cell carcinoma, basal cell epithelioma, and normal skin from iAsintoxicated patients [97-99]. Also, iAs[III] can induce 8$\mathrm{OHdG}$ and promote genomic instability by damaging DNA and inducing oncogene expression (including several factors regulating cell cycle progression) human breast cancer MCF7 adenocarcinoma epithelial cells exposed to iAs[III] [100]. Oral administration of DMA[V] increases 8-oxo-G levels through $(\mathrm{CH} 3)_{2} \mathrm{AsOO} \cdot[54,55]$.

\section{Inhibition of DNA Repair Mechanisms Associated with Arsenic Exposure}

iAs can also induce DNA damage by interfering with the DNA repair processes. Inhibition or impairment of the DNA repair processes, principally the repair of DNA strand breaks, is considered one of the main mechanisms of iAs carcinogenesis [88, 101, 102]. For example, DMA[V] affects DNA repair and replication mechanisms in human alveolar cells, leading to persistence DNA damage (mainly apurinic/apyrimidinic sites) and generating ssDNA breaks as a consequence [103, 104].

DNA base damage (induced by oxidative stress) can be repaired through excision repair mechanisms, which are subdivided into BER and nucleotide excision repair (NER) pathways [105]. BER is the predominant repair pathway for DNA lesions caused by ROS, and the first candidate in iAs-related DNA repair $[69,106]$. Transcription levels of genes related to BER mechanisms are altered in a gene, age, dose-, and duration-dependent manner in lung tissue of mice exposed to iAs [107]. On the other hand, iAs was also shown to alter BER mechanisms in GM847 lung fibroblasts and $\mathrm{HaCaT}$ keratinocytes, increasing levels of BER-related enzymes and repair capacity [108].

Several enzymes participate in the BER mechanism, some of which are known to be modulated by iAs. Among them, DNA polymerase $\beta(\operatorname{Pol} \beta)$ and DNA ligase I (LIG1) have been described as affected by As[III] [109, 110]. Normally, after generation of $5^{\prime}$ incision on an abasic site leaving a $3^{\prime}$ hydroxyl and a $5^{\prime}$-deoxyribose 5 -phosphate, $\mathrm{Pol} \beta$ hydrolyses the $5^{\prime}$-sugar phosphate and adds at least one nucleotide to the $3^{\prime}$-hydroxyl end. The remaining strand is nick sealed by LIG1, and PARP-1 may recruit the required proteins [108]. However, in lung fibroblasts and $\mathrm{HaCaT}$ keratinocytes exposed to As[III], Pol $\beta$ mRNA levels are downregulated in a dose-dependent manner (doses $>1 \mu \mathrm{M})$, and at doses lower than $1 \mu \mathrm{M}$ both $\operatorname{Pol} \beta$ mRNA and protein levels, and consequently, BER activity, were significantly increased [108]. Additionally, this enzyme is stimulated in response to low doses iAs and modulated by other sources of oxidative stress [111-114]. Interestingly DNA copy-number alterations (CNAs) in lung squamous cell carcinoma (SqCC) from iAs-exposed patients from northern Chile contain the Pol $\delta 1$ (DNA polymerase $\delta 1$, catalytic subunit), which codes for the proofreading domain of the DNA polymerase $\delta$ complex and also participates in ssDNA breaks repair process [115-119].

It has been proposed that iAs[III] works at transcriptional level to repress a group of genes encoding for DNA

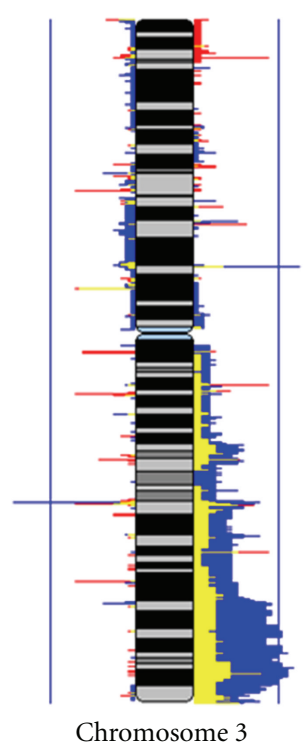

Figure 3: Comparison of CNA frequency at chromosome 3 between lung SqCC exposed and nonexposed to iAs. The figure represents a comparison of CNA frequency at chromosome 3 generated from 52 lung SqCC biopsies by using a submegabase resolution tiling-set rearray (SMRTr) platform. Of those, 22 derived from arsenic-exposed smokers and never smokers patients from Northern Chile (red) and 30 were current and ex-smokers North American patients without known arsenic exposure nonexposed (blue). Frequency of alteration results for exposed and nonexposed SqCCs cases has been overlaid in this figure, with regions in yellow, denoting a sector of overlapping alteration status in both groups. The magnitude of red, yellow and blue bars represents percentage of samples exhibiting corresponding alteration $(0-100 \%$, with blue vertical lines representing 50\% frequency). DNA gains and losses are represented to the right and left of chromosome, respectively. Adapted from Martinez et al. [115].

repair enzymes participating in BER and NER mechanisms, mainly through its downregulation. This, in combination with other events, contributes to toxicity or cancer [120]. In parallel, changes in expression levels have been also corroborated in human exposed populations. Exposure to arsenic in drinking water was correlated to decreased expression of ERCC1, XPB, and XPF in lymphocytes from exposed individuals [121]. Decreased ERCC1 gene expression was confirmed in lymphocytes treated with $>1 \mu \mathrm{M}$ of iAs[III], and a significant reduction of ERCC1 protein levels was observed among individuals exposed to drinking water with low levels of arsenic [122]. Similarly, mRNA levels of ERCC1 expression were significantly associated with arsenic concentrations in drinking water, implicating the DNA repair response was induced by arsenic exposure [123]. On the other hand, OGG1 expression (which encodes for 8oxoguanine DNA glycosylase, involved in base excision repair of 8-oxoguanine [124]) was strongly associated with arsenic concentrations [125], revealing involvement of mechanisms related the effects of arsenic-mediated ROS on DNA.

DNA ligation is a key step in DNA repair pathways [126]. Interestingly, it has been shown that iAs can specifically 
inhibit this process as well. More recently we have found that the mRNA, protein and activity levels of both DNA ligase I and ligase III are significantly reduced in mammalian cells in response to As[III] [109]. Additionally, As[III] retards DNA break rejoining by interacting with the vicinal dithiols and thus inhibiting DNA ligation [127]. Mammalian cells have been shown to exhibit a dose-dependent decrease in ligase activity with exposure to As[III], corresponding to a decrease in mRNA levels of this enzyme $[108,128]$. On the other hand, it has been also shown that LIG1 and other DNA damage/repair genes were increased by As[III] and $\mathrm{As}[\mathrm{V}]$ treatment, suggesting a cellular response to iAsinduced DNA damage [129].

Members of the poly (ADP-ribose) polymerase (PARP) family also play an important role in the regulation of DNA damage repair. PARP-1 (accounting for about 90\% of the total cellular poly ADP-ribose formation) acts as a "DNA damage sensor", exhibiting high affinity to bind both ssDNA and dsDNA breaks [130-132]. It has been proposed that lack of PARP-1 enhances cellular sensitivity to As[III] [133]. Cells deficient in this gene product display greater telomere attrition. This process can be attributable to susceptibility of the triple-G-containing structures of telomeric DNA to oxidative damage $[134,135]$. In parallel, cells deficient in PARP-1 exhibit reduced repair of 8-oxoguanine, another marker for oxidative damage that can potentially be induced by iAs [136]. Finally, specific CNAs located at located at 10q11.23 in lung SqCC from iAs-exposed patients from northern Chile contain the PARG (polyADP-ribose glycohydrolase) gene, which also participates in ssDNA breaks repair process $[102,115,137]$.

\section{Genomic Landscape of Arsenic-Related Lung Cancer}

Lungs are the most frequently affected organ by iAs, and lung cancer remains the main cause of iAs-related death [24]. Tobacco exposure is the main aetiological factor in lung cancer; however, iAs ingestion through drinking water also represents a risk factor, particularly for lung squamous cell carcinomas (SqCCs). Interestingly, the incidence of SqCC is decreasing worldwide and is usually associated with cigarette smoking, but in Northern Chilean populations exposed to arsenic contaminated drinking water, SqCC frequently occurs in never smokers, $[14,138]$ suggesting distinct molecular tumorigenic pathways may underlie arsenic-related cancers.

To this effect, it was determined if globally, there existed CNAs specific to lung SqCC cases from a Northern Chilean population chronically exposed to iAs in drinking water [115], using a whole genome tiling-path array comparative genomic hybridization (CGH) platform [139]. It was detected a surprisingly low frequency of DNA gains at chromosome arm $3 \mathrm{q}$ in lung SqCCs from arsenic-exposed individuals (Figure 3), which is remarkable, since DNA gains at $3 \mathrm{q}$ are the most widely reported alteration associated with lung SqCC tumors and cell lines [140, 141].
It was also identified specific DNA gains and losses associated with lung SqCC from never smokers exposed to iAs. For example, a specific and frequent DNA gain at 19q13.33 contains genes related to ssDNA breaks repair process (POLD1) and neoplastic processes (SPIB and NR1H2). Additionally, a widespread association of DNA copy number loss specific to iAs-exposed lung SqCC, concordant with previous findings showing that arsenic can induce multiple large deletions through the creation of ROS [142] was identified. Some of these deletions, mainly at $9 \mathrm{q} 12$, may be relevant to iAs carcinogenic mechanisms, since they have been described in other iAs-related types of cancer and involve genes from the forkhead box (Fox) gene family, which have been linked to tumorigenesis and cancer progression [143].

This recent information provides evidence of distinct CNAs associated with lung SqCC occurring in patients who had exposure to iAs in drinking water and suggests that alternative molecular pathways are activated in this disease subset.

\section{Conclusion}

Arsenic exposure through contaminated drinking water poses a major health concern for over 40 million people worldwide, where for some, arsenic levels are almost 10 times higher than recommended thresholds. In addition to causing a variety of health problems including vascular and neurological conditions, arsenic is an established carcinogen. The rate of cancer incidence and mortality in populations exposed to arsenic contaminated drinking water is alarming. These populations experience particularly exacerbated rates of cancer in organs where arsenic is most concentrated or is excreted, including lung, bladder, and skin cancers. The mechanisms of arsenic-induced carcinogenesis are slowly being elucidated through the study of the precise DNA damaging and cytotoxic properties related to the biotransformation, metabolism, and excretion of arsenic. Discovery of particular genomic and epigenomic lesions induced by this metalloid should encourage a comprehensive approach to elucidate how arsenic can induce different types of cancer. Despite histology similarity, the possibility of iAsinduced cases biologically distinct entities, compared to those induced by other environmental carcinogens, must be considered. Knowledge related to these processes may lead to specific treatment strategies targeting arsenic-induced disorders and malignancies.

\section{Acknowledgments}

This work was supported by funds from the Canadian Institutes for Health Research (CIHR; MOP 86731, MOP 94867) and a CIHR CGS scholarship to E. A. Vucic. V. D. Martinez was supported by INNOVA-Chile grant 07CN13PBT-48. 


\section{References}

[1] C. Klein, Mineral Science, Wiley, New York, NY, USA, 2002.

[2] ATSDR, A.f.T.S.a.D.R., Toxicological Profile for Arsenic, P.H.S., U.S. Department of Health and Human Services, 2007.

[3] J. M. Azcue, A. Mudroch, F. Rosa, G. E. M. Hall, T. A. Jackson, and T. Reynoldson, "Trace elements in water, sediments, porewater, and biota polluted by tailings from an abandoned gold mine in British Columbia, Canada," Journal of Geochemical Exploration, vol. 52, no. 1-2, pp. 25-34, 1995.

[4] P. L. Smedley and D. G. Kinniburgh, "A review of the source, behaviour and distribution of arsenic in natural waters," Applied Geochemistry, vol. 17, no. 5, pp. 517-568, 2002.

[5] M. Vahter and G. Concha, "Role of metabolism in arsenic toxicity," Pharmacology and Toxicology, vol. 89, no. 1, pp. 1$5,2001$.

[6] C. J. Chen, Y. M. Hsueh, M. S. Lai et al., "Increased prevalence of hypertension and long-term arsenic exposure," Hypertension, vol. 25, no. 1, pp. 53-60, 1995.

[7] R. R. Engel, C. Hopenhayn-Rich, O. Receveur, and A. H. Smith, "Vascular effects of chronic arsenic exposure: a review," Epidemiologic Reviews, vol. 16, no. 2, pp. 184-209, 1994.

[8] T. Kadono, T. Inaoka, N. Murayama et al., "Skin manifestations of arsenicosis in two villages in Bangladesh," International Journal of Dermatology, vol. 41, no. 12, pp. 841846, 2002.

[9] W. P. Tseng, H. M. Chu, S. W. How, J. M. Fong, C. S. Lin, and S. Yeh, "Prevalence of skin cancer in an endemic area of chronic arsenicism in Taiwan," Journal of the National Cancer Institute, vol. 40, no. 3, pp. 453-463, 1968.

[10] C. J. Chen and C. J. Wang, "Ecological correlation between arsenic level in well water and age-adjusted mortality from malignant neoplasms," Cancer Research, vol. 50, no. 17, pp. 5470-5474, 1990.

[11] A. H. Smith, M. Goycolea, R. Haque, and M. L. Biggs, "Marked increase in bladder and lung cancer mortality in a region of northern chile due to arsenic in drinking water," American Journal of Epidemiology, vol. 147, no. 7, pp. 660$669,1998$.

[12] C. Hopenhayn-Rich, M. L. Biggs, A. Fuchs et al., "Bladder cancer mortality associated with arsenic in drinking water in Argentina," Epidemiology, vol. 7, no. 2, pp. 117-124, 1996.

[13] K. H. Morales, L. Ryan, T. L. Kuo, M. M. Wu, and C. J. Chen, "Risk of internal cancers from arsenic in drinking water," Environmental Health Perspectives, vol. 108, no. 7, pp. 655$661,2000$.

[14] C. Ferreccio, C. González, V. Milosavjlevic, G. Marshall, A. M. Sancha, and A. H. Smith, "Lung cancer and arsenic concentrations in drinking water in Chile," Epidemiology, vol. 11, no. 6, pp. 673-679, 2000.

[15] G. Marshall, C. Ferreccio, Y. Yuan et al., "Fifty-year study of lung and bladder cancer mortality in Chile related to arsenic in drinking water," Journal of the National Cancer Institute, vol. 99, no. 12, pp. 920-928, 2007.

[16] A. H. Smith, C. Hopenhayn-Rich, M. N. Bates et al., "Cancer risks from arsenic in drinking water," Environmental Health Perspectives, vol. 97, pp. 259-267, 1992.

[17] World health Organization (WHO), Guidelines for DrinkingWater Quality, 1993.

[18] U. S. Environmental Protection Agency, Technical Fact Sheet: Final Rule for Arsenic in Drinking Water, 2001.
[19] D. K. Nordstrom, "Worldwide occurrences of arsenic in ground water," Science, vol. 296, no. 5576, pp. 2143-2145, 2002.

[20] L. R. Croal, J. A. Gralnick, D. Malasarn, and D. K. Newman, "The genetics of geochemistry," Annual Review of Genetics, vol. 38, pp. 175-202, 2004.

[21] A. Basu, J. Mahata, S. Gupta, and A. K. Giri, "Genetic toxicology of a paradoxical human carcinogen, arsenic: A review," Mutation Research, vol. 488, no. 2, pp. 171-194, 2001.

[22] B. British Geological Survey, "British Geological Survey. Groundwater Studies for Arsenic Contamination in Bangladesh," Final Report, Mott MacDonald Ltd., 1999.

[23] R. Nickson, J. McArthur, W. Burgess, K. Matin Ahmed, P. Ravenscroft, and M. Rahman, "Arsenic poisoning of Bangladesh groundwater," Nature, vol. 395, no. 6700, p. 338, 1998.

[24] M. N. Mead, "Arsenic: in search of an antidote to a global poison," Environmental Health Perspectives, vol. 113, no. 6, pp. A378-A386, 2005.

[25] W. P. Tseng, "Effects and dose response relationships of skin cancer and blackfoot disease with arsenic," Environmental Health Perspectives, vol. 19, pp. 109-119, 1977.

[26] C.-J. Chen, M.-M. Wu, S.-S. Lee, J.-D. Wang, S.-H. Cheng, and H.-Y. Wu, "Atherogenicity and carcinogenicity of higharsenic artesian well water. Multiple risk factors and related malignant neoplasms of blackfoot disease," Arteriosclerosis, vol. 8, no. 5, pp. 452-460, 1988.

[27] R. Blackwell, "Estimation total arsenic ingested by residents in Ihe endemic blackfoot area," Journal of the Formosan Medical Association, vol. 60, pp. 1143-1144, 1961.

[28] G. B. Freeman, R. A. Schoof, M. V. Ruby et al., "Bioavailability of arsenic in soil and house dust impacted by smelter activities following oral administration in cynomolgus monkeys," Fundamental and Applied Toxicology, vol. 28, no. 2, pp. 215-222, 1995.

[29] C. Pomroy, S. M. Charbonneau, R. S. McCullough, and G. K. H. Tam, "Human retention studies with 74As," Toxicology and Applied Pharmacology, vol. 53, no. 3, pp. 550-556, 1980.

[30] M. Vahter and H. Norin, "Metabolism of 74As-labeled trivalent and pentavalent inorganic arsenic in mice," Environmental Research, vol. 21, no. 2, pp. 446-457, 1980.

[31] World health Organization (WHO), Air Quality Guidelines, W.R. Publications, WHO Regional Office for Europe, Copenhagen, Denmark, 2nd edition, 2000.

[32] E. Marafante, M. Vahter, and J. Envall, "The role of the methylation in the detoxication of arsenate in the rabbit," Chemico-Biological Interactions, vol. 56, no. 2-3, pp. 225-238, 1985.

[33] M. Vahter and E. Marafante, "Reduction and binding of arsenate in marmoset monkeys," Archives of Toxicology, vol. 57, no. 2, pp. 119-124, 1985.

[34] M. Vahter, "Methylation of inorganic arsenic in different mammalian species and population groups," Science Progress, vol. 82, part 1, pp. 69-88, 1999.

[35] M. Vahter, "Genetic polymorphism in the biotransformation of inorganic arsenic and its role in toxicity," Toxicology Letters, vol. 112-113, pp. 209-217, 2000.

[36] D. J. Thompson, "A chemical hypothesis for arsenic methylation in mammals," Chemico-Biological Interactions, vol. 88, no. 2-3, pp. 89-114, 1993. 
[37] S. Lin, Q. Shi, F. Brent Nix et al., "A novel S-adenosylL-methionine:arsenic(III) methyltransferase from rat liver cytosol," Journal of Biological Chemistry, vol. 277, no. 13, pp. 10795-10803, 2002.

[38] B. K. Mandal, Y. Ogra, and K. T. Suzuki, "Identification of dimethylarsinous and monomethylarsonous acids in human urine of the arsenic-affected areas in West Bengal, India," Chemical Research in Toxicology, vol. 14, no. 4, pp. 371-378, 2001.

[39] H. V. Aposhian, E. S. Gurzau, X. C. Le et al., "Occurrence of monomethylarsonous acid in urine of humans exposed to inorganic arsenic," Chemical Research in Toxicology, vol. 13, no. 8, pp. 693-697, 2000.

[40] M. M. Meza, M. J. Kopplin, J. L. Burgess, and A. J. Gandolfi, "Arsenic drinking water exposure and urinary excretion among adults in the Yaqui Valley, Sonora, Mexico," Environmental Research, vol. 96, no. 2, pp. 119-126, 2004.

[41] T. Hayakawa, Y. Kobayashi, X. Cui, and S. Hirano, "A new metabolic pathway of arsenite: arsenic-glutathione complexes are substrates for human arsenic methyltransferase Cyt19," Archives of Toxicology, vol. 79, no. 4, pp. 183-191, 2005.

[42] C. Kojima, D. C. Ramirez, E. J. Tokar et al., "Requirement of arsenic biomethylation for oxidative DNA damage," Journal of the National Cancer Institute, vol. 101, no. 24, pp. 16701681, 2009.

[43] M. I. Ekstrand, M. Falkenberg, A. Rantanen et al., "Mitochondrial transcription factor A regulates mtDNA copy number in mammals," Human Molecular Genetics, vol. 13, no. 9, pp. 935-944, 2004.

[44] T. Kanki, K. Ohgaki, M. Gaspari et al., "Architectural role of mitochondrial transcription factor a in maintenance of human mitochondrial DNA," Molecular and Cellular Biology, vol. 24, no. 22, pp. 9823-9834, 2004.

[45] K. P. Singh, R. Kumari, J. Treas, and J. W. Dumond, "Chronic exposure to arsenic causes increased cell survival, DNA damage, and increased expression of mitochondrial transcription factor A (mtTFA) in human prostate epithelial cells," Chemical Research in Toxicology, vol. 24, no. 3, pp. 340349, 2011.

[46] T. G. Rossman, "Mechanism of arsenic carcinogenesis: an integrated approach," Mutation Research, vol. 533, no. 1-2, pp. 37-65, 2003.

[47] J. C. Barrett, P. W. Lamb, T. C. Wang, and T. C. Lee, "Mechanism of arsenic-induced cell transformation," Biological Trace Element Research, vol. 21, pp. 421-429, 1989.

[48] P. P. Simeonova and M. I. Luster, "Mechanisms of arsenic carcinogenicity: genetic or epigenetic mechanisms?" Journal of Environmental Pathology, Toxicology and Oncology, vol. 19, no. 3, pp. 281-286, 2000.

[49] M. Styblo, L. M. Del Razo, L. Vega et al., "Comparative toxicity of trivalent and pentavalent inorganic and methylated arsenicals in rat and human cells," Archives of Toxicology, vol. 74, no. 6, pp. 289-299, 2000.

[50] J. S. Petrick, F. Ayala-Fierro, W. R. Cullen, D. E. Carter, and H. Vasken Aposhian, "Monomethylarsonous acid (MMA(III)) is more toxic than arsenite in Chang human hepatocytes," Toxicology and Applied Pharmacology, vol. 163, no. 2, pp. 203-207, 2000.

[51] M. J. Mass, A. Tennant, B. C. Roop et al., "Methylated trivalent arsenic species are genotoxic," Chemical Research in Toxicology, vol. 14, no. 4, pp. 355-361, 2001.

[52] S. Ahmad, K. T. Kitchin, and W. R. Cullen, "Arsenic species that cause release of iron from ferritin and generation of activated oxygen," Archives of Biochemistry and Biophysics, vol. 382, no. 2, pp. 195-202, 2000.

[53] K. Yamanaka, M. Mizoi, M. Tachikawa, A. Hasegawa, M. Hoshino, and S. Okada, "Oxidative DNA damage following exposure to dimethylarsinous iodide: the formation of cisthymine glycol," Toxicology Letters, vol. 143, no. 2, pp. 145153, 2003.

[54] K. Yamanaka, M. Mizoi, K. Kato, A. Hasegawa, M. Nakano, and S. Okada, "Oral administration of dimethylarsinic acid, a main metabolite of inorganic arsenic, in mice promotes skin tumorigenesis initiated by dimethylbenz(a)anthracene with or without ultraviolet B as a promoter," Biological and Pharmaceutical Bulletin, vol. 24, no. 5, pp. 510-514, 2001.

[55] K. Yamanaka, K. Katsumata, K. Ikuma, A. Hasegawa, M. Nakano, and S. Okada, "The role of orally administered dimethylarsinic acid, a main metabolite of inorganic arsenics, in the promotion and progression of UVB-induced skin tumorigenesis in hairless mice," Cancer Letters, vol. 152, no. 1, pp. 79-85, 2000.

[56] M. Wei, H. Wanibuchi, S. Yamamoto, W. Li, and S. Fukushima, "Urinary bladder carcinogenicity of dimethylarsinic acid in male F344 rats," Carcinogenesis, vol. 20, no. 9, pp. 1873-1876, 1999.

[57] H. Wanibuchi, S. Yamamoto, H. Chen et al., "Promoting effects of dimethylarsinic acid on N-butyl-N-(4hydroxybutyl)nitrosamine-induced urinary bladder carcinogenesis in rats," Carcinogenesis, vol. 17, no. 11, pp. 2435-2439, 1996.

[58] S. Yamamoto, Y. Konishi, T. Matsuda et al., "Cancer induction by an organic arsenic compound, dimethylarsinic acid (cacodylic acid), in F344/DuCrj rats after pretreatment with five carcinogens," Cancer Research, vol. 55, no. 6, pp. 12711276, 1995.

[59] M. Kessel, S. X. Liu, A. Xu, R. Santella, and T. K. Hei, "Arsenic induces oxidative DNA damage in mammalian cells," Molecular and Cellular Biochemistry, vol. 234-235, pp. 301-308, 2002.

[60] K. T. Kitchin and S. Ahmad, "Oxidative stress as a possible mode of action for arsenic carcinogenesis," Toxicology Letters, vol. 137, no. 1-2, pp. 3-13, 2003.

[61] H. Shi, X. Shi, and K. J. Liu, "Oxidative mechanism of arsenic toxicity and carcinogenesis," Molecular and Cellular Biochemistry, vol. 255, no. 1-2, pp. 67-78, 2004.

[62] R. C. Lantz and A. M. Hays, "Role of oxidative stress in arsenic-induced toxicity," Drug Metabolism Reviews, vol. 38, no. 4, pp. 791-804, 2006.

[63] M. Valko, C. J. Rhodes, J. Moncol, M. Izakovic, and M. Mazur, "Free radicals, metals and antioxidants in oxidative stress-induced cancer," Chemico-Biological Interactions, vol. 160, no. 1, pp. 1-40, 2006.

[64] A. De Vizcaya-Ruiz, O. Barbier, R. Ruiz-Ramos, and M. E. Cebrian, "Biomarkers of oxidative stress and damage in human populations exposed to arsenic," Mutation Research, vol. 674, no. 1-2, pp. 85-92, 2009.

[65] K. T. Kitchin and R. Conolly, "Arsenic-induced carcinogenesissoxidative stress as a possible mode of action and future research needs for more biologically based risk assessment," Chemical Research in Toxicology, vol. 23, no. 2, pp. 327-335, 2010.

[66] A. Barchowsky, L. R. Klei, E. J. Dudek, H. M. Swartz, and P. E. James, "Stimulation of reactive oxygen, but not reactive nitrogen species, in vascular endothelial cells exposed to low 
levels of arsenite," Free Radical Biology and Medicine, vol. 27, no. 11-12, pp. 1405-1412, 1999.

[67] F. Liu and K. Y. Jan, "DNA damage in arsenite- and cadmium-treated bovine aortic en-do-the-lial cells," Free Radical Biology and Medicine, vol. 28, no. 1, pp. 55-63, 2000.

[68] S. J. S. Flora, "Arsenic-induced oxidative stress and its reversibility following combined administration of $\mathrm{N}$ acetylcysteine and meso 2,3-dimercaptosuccinic acid in rats," Clinical and Experimental Pharmacology and Physiology, vol. 26, no. 11, pp. 865-869, 1999.

[69] S. X. Liu, M. Athar, I. Lippai, C. Waldren, and T. K. Hei, "Induction of oxyradicals by arsenic: implication for mechanism of genotoxicity," Proceedings of the National Academy of Sciences of the United States of America, vol. 98, no. 4, pp. 1643-1648, 2001.

[70] K. Yamanaka and S. Okada, "Induction of lung-specific DNA damage by metabolically methylated arsenics via the production of free radicals," Environmental Health Perspectives, vol. 102, no. 3, pp. 37-40, 1994.

[71] E. M. Kenyon, M. F. Hughes, B. M. Adair et al., "Tissue distribution and urinary excretion of inorganic arsenic and its methylated metabolites in C57BL6 mice following subchronic exposure to arsenate in drinking water," Toxicology and Applied Pharmacology, vol. 232, no. 3, pp. 448-455, 2008.

[72] S. Ahmad, K. T. Kitchin, and W. R. Cullen, "Plasmid DNA damage caused by methylated arsenicals, ascorbic acid and human liver ferritin," Toxicology Letters, vol. 133, no. 1, pp. 47-57, 2002.

[73] M. A. Partridge, S. X. L. Huang, E. Hernandez-Rosa, M. M. Davidson, and T. K. Hei, "Arsenic induced mitochondrial DNA damage and altered mitochondrial oxidative function: implications for genotoxic mechanisms in mammalian cells," Cancer Research, vol. 67, no. 11, pp. 5239-5247, 2007.

[74] S. X. Liu, M. M. Davidson, X. Tang et al., "Mitochondrial damage mediates genotoxicity of arsenic in mammalian cells," Cancer Research, vol. 65, no. 8, pp. 3236-3242, 2005.

[75] S. H. Woo, I. C. Park, M. J. Park et al., "Arsenic trioxide induces apoptosis through a reactive oxygen speciesdependent pathway and loss of mitochondrial membrane potential in HeLa cells," International Journal of Oncology, vol. 21, no. 1, pp. 57-63, 2002.

[76] S. J. Flora, "Arsenic-induced oxidative stress and its reversibility," Free Radical Biology \& Medicine, vol. 51, no. 2, pp. 257281, 2011.

[77] J. H. Li and T. G. Rossman, "Comutagenesis of sodium arsenite with ultraviolet radiation in Chinese hamster V79 cells," Biology of Metals, vol. 4, no. 4, pp. 197-200, 1991.

[78] T. K. Hei, S. U. X. Liu, and C. Waldren, "Mutagenicity of arsenic in mammalian cells: role of reactive oxygen species," Proceedings of the National Academy of Sciences of the United States of America, vol. 95, no. 14, pp. 8103-8107, 1998.

[79] K. P. Singh and J. W. DuMond, "Genetic and epigenetic changes induced by chronic low dose exposure to arsenic of mouse testicular Leydig cells," International Journal of Oncology, vol. 30, no. 1, pp. 253-260, 2007.

[80] A. D. Kligerman, C. L. Doerr, A. H. Tennant et al., "Methylated trivalent arsenicals as candidate ultimate genotoxic forms of arsenic: induction of chromosomal mutations but not gene mutations," Environmental and Molecular Mutagenesis, vol. 42, no. 3, pp. 192-205, 2003.

[81] K. T. Kitchin and K. Wallace, "Evidence against the nuclear in situ binding of arsenicals-oxidative stress theory of arsenic carcinogenesis," Toxicology and Applied Pharmacology, vol. 232, no. 2, pp. 252-257, 2008.

[82] B. Halliwell, "Oxidative stress and cancer: have we moved forward?” Biochemical Journal, vol. 401, no. 1, pp. 1-11, 2007.

[83] K. W. Caldecott, "DNA single-strand breaks and neurodegeneration," DNA Repair, vol. 3, no. 8-9, pp. 875-882, 2004.

[84] A. D. Kligerman, S. I. Malik, and J. A. Campbell, "Cytogenetic insights into DNA damage and repair of lesions induced by a monomethylated trivalent arsenical.," Mutation Research, vol. 695, no. 1-2, pp. 2-8, 2010.

[85] S. A. Mourón, C. A. Grillo, F. N. Dulout, and C. D. Golijow, "Induction of DNA strand breaks, DNA-protein crosslinks and sister chromatid exchanges by arsenite in a human lung cell line," Toxicology in Vitro, vol. 20, no. 3, pp. 279-285, 2006.

[86] S. Ying, K. Myers, S. Bottomley, T. Helleday, and H. E. Bryant, "BRCA2-dependent homologous recombination is required for repair of Arsenite-induced replication lesions in mammalian cells," Nucleic Acids Research, vol. 37, no. 15, pp. 5105-5113, 2009.

[87] T. Helleday, J. Lo, D. C. van Gent, and B. P. Engelward, "DNA double-strand break repair: from mechanistic understanding to cancer treatment," DNA Repair, vol. 6, no. 7, pp. 923-935, 2007.

[88] X. J. Qin, L. G. Hudson, W. Liu, G. S. Timmins, and K. J. Liu, "Low concentration of arsenite exacerbates UVR-induced DNA strand breaks by inhibiting PARP-1 activity," Toxicology and Applied Pharmacology, vol. 232, no. 1, pp. 41-50, 2008.

[89] A. D. Kligerman and A. H. Tennant, "Insights into the carcinogenic mode of action of arsenic," Toxicology and Applied Pharmacology, vol. 222, no. 3, pp. 281-288, 2007.

[90] T. C. Lee, N. Tanaka, P. W. Lamb, T. M. Gilmer, and J. C. Barrett, "Induction of gene amplification by arsenic," Science, vol. 241, no. 4861, pp. 79-81, 1988.

[91] F. W. Alt, R. E. Kellems, J. R. Bertino, and R. T. Schimke, "Selective multiplication of dihydrofolate reductase genes in methotrexate-resistant variants of cultured murine cells," Journal of Biological Chemistry, vol. 253, no. 5, pp. 13571370, 1978.

[92] L. E. Moore, A. H. Smith, C. Eng et al., "Arsenic-related chromosomal alterations in bladder cancer," Journal of the National Cancer Institute, vol. 94, no. 22, pp. 1688-1696, 2002.

[93] L. I. Hsu, A. W. Chiu, Y. S. Pu et al., "Comparative genomic hybridization study of arsenic-exposed and non-arsenicexposed urinary transitional cell carcinoma," Toxicology and Applied Pharmacology, vol. 227, no. 2, pp. 229-238, 2008.

[94] M. E. Gonsebatt, L. Vega, A. M. Salazar et al., "Cytogenetic effects in human exposure to arsenic," Mutation Research, vol. 386, no. 3, pp. 219-228, 1997.

[95] F. N. Dulout, C. A. Grillo, A. I. Seoane et al., "Chromosomal aberrations in peripheral blood lymphocytes from native Andean women and children from Northwestern Argentina exposed to arsenic in drinking water," Mutation Research, vol. 370, no. 3-4, pp. 151-158, 1996.

[96] Y. An, K. Kato, M. Nakano, H. Otsu, S. Okada, and K. Yamanaka, "Specific induction of oxidative stress in terminal bronchiolar Clara cells during dimethylarsenic-induced lung tumor promoting process in mice," Cancer Letters, vol. 230, no. 1, pp. 57-64, 2005.

[97] Y. An, Z. Gao, Z. Wang et al., "Immunohistochemical analysis of oxidative DNA damage in arsenic-related human skin 
samples from arsenic-contaminated area of China," Cancer Letters, vol. 214, no. 1, pp. 11-18, 2004.

[98] M. Matsui, C. Nishigori, S. Toyokuni et al., "The role of oxidative DNA damage in human arsenic carcinogenesis: detection of 8-hydroxy-2'-deoxyguanosine in arsenic-related Bowen's disease," Journal of Investigative Dermatology, vol. 113, no. 1, pp. 26-31, 1999.

[99] H. Wanibuchi, T. Hori, V. Meenakshi et al., "Promotion of rat hepatocarcinogenesis by dimethylarsinic acid: association with elevated ornithine decarboxylase activity and formation of 8-hydroxydeoxyguanosine in the liver," Japanese Journal of Cancer Research, vol. 88, no. 12, pp. 1149-1154, 1997.

[100] R. Ruiz-Ramos, L. Lopez-Carrillo, A. D. Rios-Perez, A. De Vizcaya-Ruíz, and M. E. Cebrian, "Sodium arsenite induces ROS generation, DNA oxidative damage, HO-1 and c-Myc proteins, NF- $\kappa \mathrm{B}$ activation and cell proliferation in human breast cancer MCF-7 cells," Mutation Research, vol. 674, no. 1-2, pp. 109-115, 2009.

[101] A. Hartwig, H. Blessing, T. Schwerdtle, and I. Walter, "Modulation of DNA repair processes by arsenic and selenium compounds," Toxicology, vol. 193, no. 1-2, pp. 161-167, 2003.

[102] A. E. O. Fisher, H. Hochegger, S. Takeda, and K. W. Caldecott, "Poly(ADP-ribose) polymerase 1 accelerates single-strand break repair in concert with poly(ADP-ribose) glycohydrolase," Molecular and Cellular Biology, vol. 27, no. 15, pp. 5597-5605, 2007.

[103] K. Yamanaka, H. Hayashi, K. Kalo, A. Hasegawa, and S. Okada, "Involvement of pref-er-ential formation of apurinic/apyrimidinic sites in dimethylarsenic-induced DNA strand breaks and DNA-protein crosslinks in cultured alveolar epithelial cells," Biochemical and Biophysical Research Communications, vol. 207, no. 1, pp. 244-249, 1995.

[104] K. Yamanaka, H. Hayashi, M. Tachikawa et al., "Metabolic methylation is a possible genotoxicity-enhancing process of inorganic arsenics," Mutation Research, vol. 394, no. 1-3, pp. 95-101, 1997.

[105] J. de Boer and J. H. J. Hoeijmakers, "Nucleotide excision repair and human syndromes," Carcinogenesis, vol. 21, no. 3, pp. 453-460, 2000.

[106] T. Schwerdtle, I. Walter, and A. Hartwig, "Arsenite and its biomethylated metabolites interfere with the formation and repair of stable BPDE-induced DNA adducts in human cells and impair XPAzf and Fpg," DNA Repair, vol. 2, no. 12, pp. 1449-1463, 2003.

[107] M. J. Osmond, B. A. Kunz, and E. T. Snow, "Age and exposure to arsenic alter base excision repair transcript levels in mice," Mutagenesis, vol. 25, no. 5, pp. 517-522, 2010.

[108] P. Sykora and E. T. Snow, "Modulation of DNA polymerase beta-dependent base excision repair in cultured human cells after low dose exposure to arsenite," Toxicology and Applied Pharmacology, vol. 228, no. 3, pp. 385-394, 2008.

[109] E. T. Snow, Y. Hu, C. B. Klein, K. L. McCluskey, M. Schuliga, and P. Sykora, "Regulation of redox and DNA repair genes by arsenic: low dose protection against oxidative stress?" in Arsenic Exposure and Health Effects V, W. R. Chappel, C. O. Abernathy, R. L. Calderon, and D. J. Thomas, Eds., pp. 305319, Elsevier Science, San Diego, Calif, USA, 2003.

[110] E. T. Snow, Y. Hu, C. C. Yan, and S. Chouchane, "Modulation of DNA repair and glutathione levels in human keratinocytes by micromolar arsenite," in Proceedings of the 3rd International Conference on Arsenic Exposure and Health Effects, W. R. Chappel, C. O. Abernathy, and R. L. Calderon, Eds., pp. 243-251, Elsevier Science, Oxford, UK, 1999.
[111] T. C. Zhang, M. T. Schmitt, and J. L. Mumford, "Effects of arsenic on telomerase and telomeres in relation to cell proliferation and apoptosis in human keratinocytes and leukemia cells in vitro," Carcinogenesis, vol. 24, no. 11, pp. 1811-1817, 2003.

[112] D. C. Cabelof, J. J. Raffoul, S. Yanamadala, Z. Guo, and A. R. Heydari, "Induction of DNA polymerase $\beta$-dependent base excision repair in response to oxidative stress in vivo," Carcinogenesis, vol. 23, no. 9, pp. 1419-1425, 2002.

[113] K. H. Chen, D. K. Srivastava, R. K. Singhal, S. Jacob, A. E. Ahmed, and S. H. Wilson, "Modulation of base excision repair by low density lipoprotein, oxidized low density lipoprotein and antioxidants in mouse monocytes," Carcinogenesis, vol. 21, no. 5, pp. 1017-1022, 2000.

[114] K. H. Chen, F. M. Yakes, D. K. Srivastava et al., "Upregulation of base excision repair correlates with enhanced protection against a DNA damaging agent in mouse cell lines," Nucleic Acids Research, vol. 26, no. 8, pp. 2001-2007, 1998.

[115] V. D. Martinez, T. P. H. Buys, M. Adonis et al., "Arsenicrelated DNA copy-number alterations in lung squamous cell carcinomas," British Journal of Cancer, vol. 103, no. 8, pp. 1277-1283, 2010.

[116] C. Nishida, P. Reinhard, and S. Linn, "DNA repair synthesis in human fibroblasts requires DNA plymerase $\delta$," Journal of Biological Chemistry, vol. 263, no. 1, pp. 501-510, 1988.

[117] J. L. Parsons, B. D. Preston, T. R. O’Connor, and G. L. Dianov, "DNA polymerase $\delta$-dependent repair of DNA single strand breaks containing $3^{\prime}$-end proximal lesions," Nucleic Acids Research, vol. 35, no. 4, pp. 1054-1063, 2007.

[118] R. E. Goldsby, L. E. Hays, X. Chen et al., "High incidence of epithelial cancers in mice deficient for DNA polymerase $\delta$ proofreading," Proceedings of the National Academy of Sciences of the United States of America, vol. 99, no. 24, pp. 15560-15565, 2002.

[119] R. N. Venkatesan, P. M. Treuting, E. D. Fuller et al., "Mutation at the polymerase active site of mouse DNA polymerase $\delta$ increases genomic instability and accelerates tumorigenesis," Molecular and Cellular Biology, vol. 27, no. 21, pp. 7669-7682, 2007.

[120] H. K. Hamadeh, K. J. Trouba, R. P. Amin, C. A. Afshari, and D. Germolec, "Coordination of altered DNA repair and damage pathways in arsenite-exposed keratinocytes," Toxicological Sciences, vol. 69, no. 2, pp. 306-316, 2002.

[121] A. S. Andrew, M. R. Karagas, and J. W. Hamilton, "Decreased DNA repair gene expression among individuals exposed to arsenic in United States drinking water," International Journal of Cancer, vol. 104, no. 3, pp. 263-268, 2003.

[122] A. S. Andrew, J. L. Burgess, M. M. Meza et al., "Arsenic exposure is associated with decreased DNA repair in vitro and in individuals exposed to drinking water arsenic," Environmental Health Perspectives, vol. 114, no. 8, pp. 11931198, 2006.

[123] J. Mo, Y. Xia, Z. Ning, T. J. Wade, and J. L. Mumford, "Elevated ERCC1 gene expression in blood cells associated with exposure to arsenic from drinking water in inner Mongolia," Anticancer Research, vol. 29, no. 8, pp. 3253-3259, 2009.

[124] A. Memisoglu and L. Samson, "Base excision repair in yeast and mammals," Mutation Research, vol. 451, no. 1-2, pp. 39$51,2000$.

[125] J. Mo, Y. Xia, T. J. Wade et al., "Chronic arsenic exposure and oxidative stress: OGG1 expression and arsenic exposure, 
nail selenium, and skin hyperkeratosis in inner Mongolia," Environmental Health Perspectives, vol. 114, no. 6, pp. 835841, 2006.

[126] T. Lindahl and R. D. Wood, "Quality control by DNA repair," Science, vol. 286, no. 5446, pp. 1897-1905, 1999.

[127] S. Lynn, H. T. Lai, J. R. Gurr, and K. Y. Jan, "Arsenite retards DNA break rejoining by inhibiting DNA ligation," Mutagenesis, vol. 12, no. 5, pp. 353-358, 1997.

[128] Y. Hu, L. Su, and E. T. Snow, "Arsenic toxicity is enzyme specific and its affects on ligation are not caused by the direct inhibition of DNA repair enzymes," Mutation Research, vol. 408, no. 3, pp. 203-218, 1998.

[129] J. Liu, M. B. Kadiiska, Y. Liu, T. Lu, W. Qu, and M. P. Waalkes, "Stress-related gene expression in mice treated with inorganic arsenicals," Toxicological Sciences, vol. 61, no. 2, pp. 314-320, 2001.

[130] S. Shall and G. De Murcia, "Poly(ADP-ribose) polymerase1: what have we learned from the deficient mouse model?" Mutation Research, vol. 460, no. 1, pp. 1-15, 2000.

[131] A. Bürkle, J. Diefenbach, C. Brabeck, and S. Beneke, "Ageing and PARP," Pharmacological Research, vol. 52, no. 1, pp. 9399, 2005.

[132] V. Schreiber, F. Dantzer, J. C. Amé, and G. De Murcia, "Poly(ADP-ribose): novel functions for an old molecule," Nature Reviews Molecular Cell Biology, vol. 7, no. 7, pp. 517$528,2006$.

[133] A. Poonepalli, L. Balakrishnan, A. K. Khaw et al., "Lack of poly(ADP-ribose) polymerase-1 gene product enhances cellular sensitivity to arsenite," Cancer Research, vol. 65, no. 23, pp. 10977-10983, 2005.

[134] F. Le Page, V. Schreiber, C. Dhérin, G. De Murcia, and S. Boiteux, "Poly(ADP-ribose) polymerase-1 (PARP-1) is required in murine cell lines for base excision repair of oxidative DNA damage in the absence of DNA polymerase $\beta$," Journal of Biological Chemistry, vol. 278, no. 20, pp. 1847118477, 2003.

[135] S. Petersen, G. Saretzki, and T. von Zglinicki, "Preferential accumulation of single-stranded regions in telomeres of human fibroblasts," Experimental Cell Research, vol. 239, no. 1, pp. 152-160, 1998.

[136] F. Dantzer, G. De La Rubia, J. Ménissier-De Murcia, Z. Hostomsky, G. De Murcia, and V. Schreiber, "Base excision repair is impaired in mammalian cells lacking poly(ADPribose) polymerase-1," Biochemistry, vol. 39, no. 25, pp. 7559-7569, 2000.

[137] H. Gao, D. L. Coyle, M. L. Meyer-Ficca et al., "Altered poly(ADP-ribose) metabolism impairs cellular responses to genotoxic stress in a hypomorphic mutant of poly(ADPribose) glycohydrolase," Experimental Cell Research, vol. 313, no. 5, pp. 984-996, 2007.

[138] S. Sun, J. H. Schiller, and A. F. Gazdar, "Lung cancer in never smokers-a different disease," Nature Reviews Cancer, vol. 7, no. 10, pp. 778-790, 2007.

[139] S. K. Watson, R. J. deLeeuw, D. E. Horsman, J. A. Squire, and W. L. Lam, "Cytogenetically balanced translocations are associated with focal copy number alterations," Human Genetics, vol. 120, no. 6, pp. 795-805, 2007.

[140] G. Tonon, K. K. Wong, G. Maulik et al., "High-resolution genomic profiles of human lung cancer," Proceedings of the National Academy of Sciences of the United States of America, vol. 102, no. 27, pp. 9625-9630, 2005.

[141] C. Garnis, W. W. Lockwood, E. Vucic et al., "High resolution analysis of non-small cell lung cancer cell lines by whole genome tiling path array CGH," International Journal of Cancer, vol. 118, no. 6, pp. 1556-1564, 2006.

[142] G. Concha, G. Vogler, D. Lezcano, B. Nermell, and M. Vahter, "Exposure to inorganic arsenic metabolites during early human development," Toxicological Sciences, vol. 44, no. 2, pp. 185-190, 1998.

[143] I. M. Kim, T. Ackerson, S. Ramakrishna et al., "The Forkhead Box $\mathrm{ml}$ transcription factor stimulates the proliferation of tumor cells during development of lung cancer," Cancer Research, vol. 66, no. 4, pp. 2153-2161, 2006. 

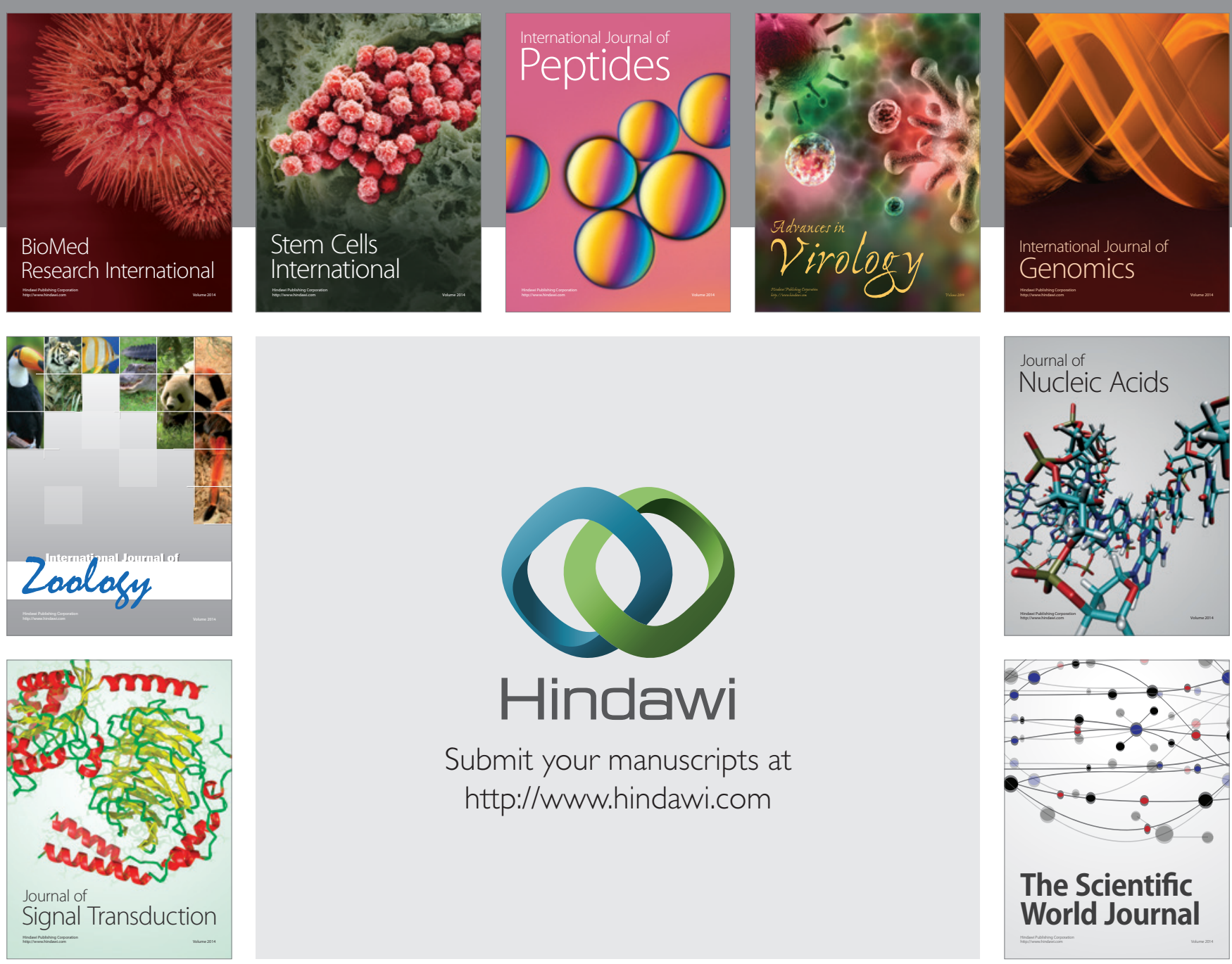

Submit your manuscripts at

http://www.hindawi.com
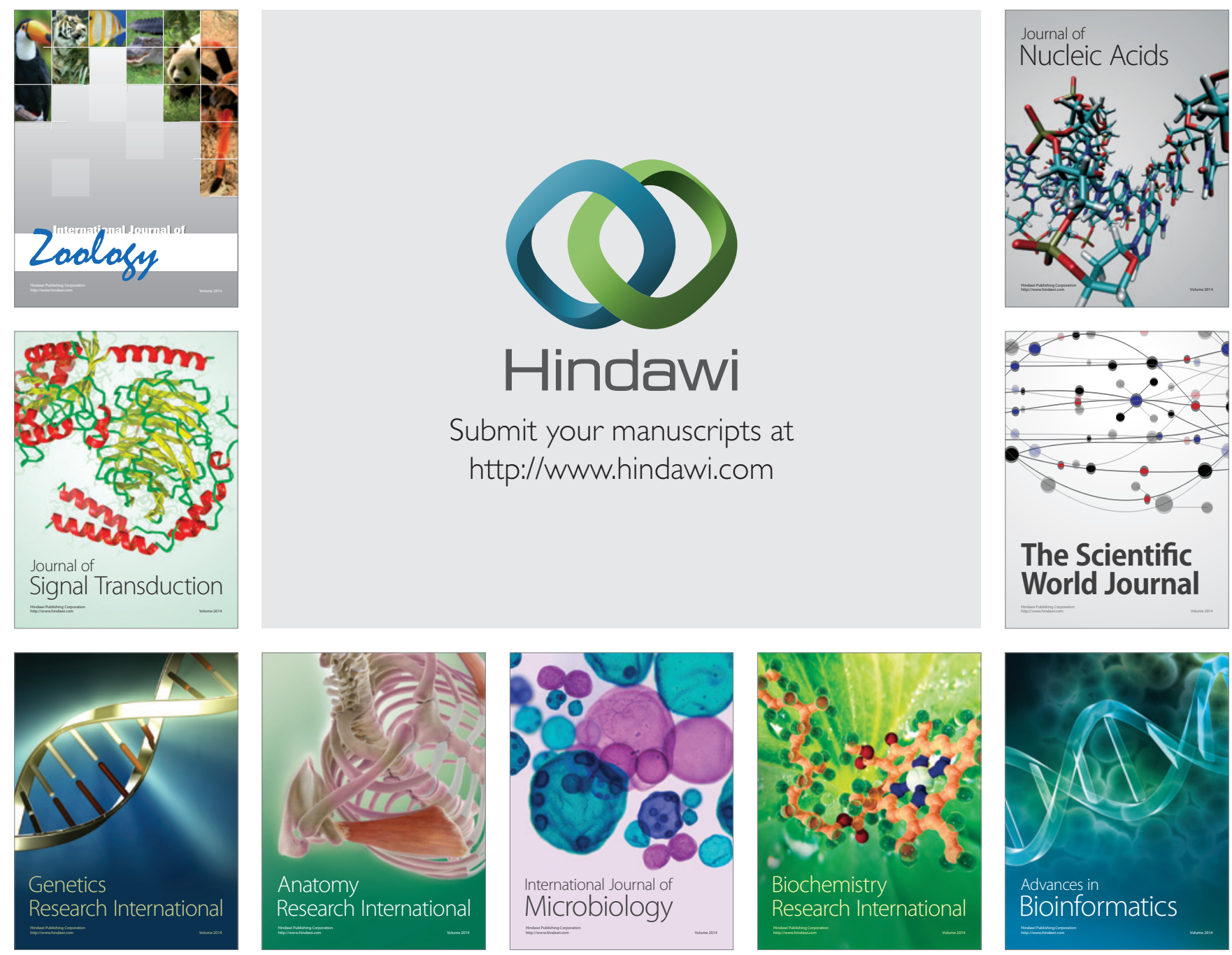

The Scientific World Journal
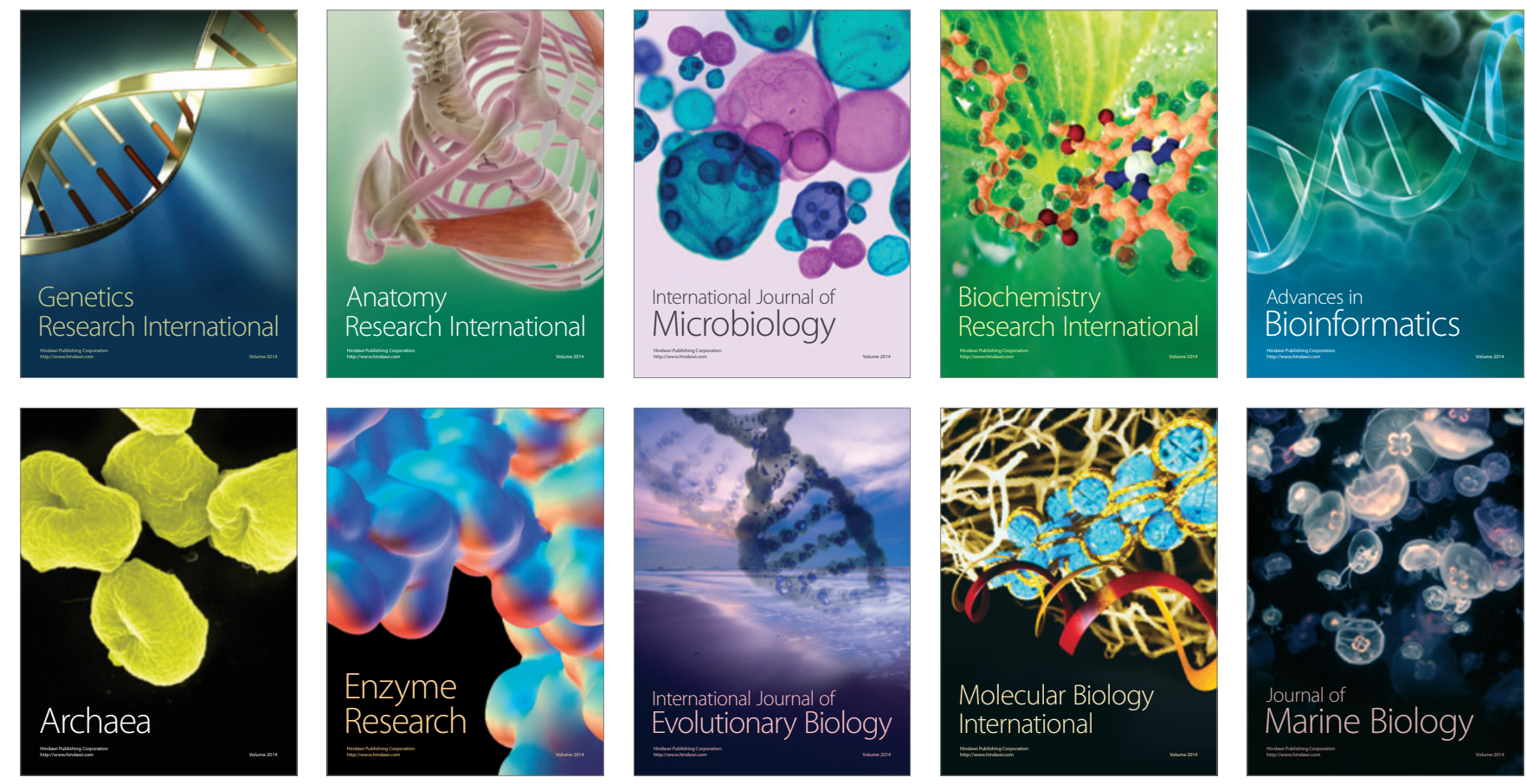